\title{
PELATIHAN PEMBUATAN VCO UNTUK MENINGKATKAN PENGHASILAN MASYARAKAT
}

\author{
VCO MAKING-TRAINING TO INCREASE COMMUNITY INCOME \\ ${ }^{1)}$ Putri Sapira Ibrahim, ${ }^{2)}$ Rosdiani Azis, ${ }^{3)}$ Ingka Rizkyani Akolo \\ ${ }^{1,2,3)}$ Program Studi Teknologi Hasil Pertanian, Politeknik Gorontalo \\ J1. Muchlis Rahim, Panggulo Barat, Kec. Botupingge Kab. Bone Bolango, Gorontalo \\ email: putrisaphiraibrahim@gmail.com
}

\begin{abstract}
ABSTRAK
Di Desa Posso belum ada pengrajin VCO, padahal desa ini memiliki potensi kelapa yang besar. Oleh karena itu membutuhkan sosialisasi kepada masyarakat cara pengolahan kelapa menjadi VCO. Tujuan kegiatan ini adalah untuk meningkatkan penghasilan mitra yakni masyarakat di Desa Posso, Kabupaten Gorontalo Utara, Provinsi Gorontalo. Metode yang digunakan adalah penyuluhan dan praktek mengolak diversifikasi produk berbahan dasar kelapa. Adapun metode pembuatan VCO yang digunakan adalah dengan menggunakan enzim yang berasal dari alam yakni enzim papain yang berfungsi untuk memisahkan antara krim santan dan minyak VCO yang dihasilkan. Hasil yang diperoleh adalah mitra mampu memproduksi VCO secara mandiri, mitra memiliki pengetahuan tentang potensi alam yang dapat dimanfaatkan untuk membuat VCO. Setelah pengabdian ini dilakukan, mitra mulai menyadari pentingnya pengolahan hasil pertanian untuk meningkatkan pendapatan dan memasarkan produknya di sekitaran daerah Gorontalo Utara.
\end{abstract}

Kata kunci: Pelatihan; Pembuatan minyak VCO; Olahan Kelapa

\section{ABSTRACT}

In Posso Village, there are no VCO craftsmen yet, even though this village has great coconut potential. Therefore, it requires socialization to the community on how to process coconut into VCO. The purpose of this activity is to increase the income of partners namely the community in Posso Village, North Gorontalo District, Gorontalo Province. The method used is counseling and the practice of refusing diversification of coconut-based products. The process of making VCO used is to use an enzyme that comes from nature, namely the papain enzyme which functions to separate the coconut milk cream and the VCO oil produced. The results obtained are partners able to produce VCO independently; partners know the natural potential that can be utilized to make VCO. After this service was carried out, partners began to realize the importance of processing agricultural products to increase income and market their products in the surrounding areas of North Gorontalo.

Keywords: Training; VCO oil making; Processed Coconut

Submitted: 26 September 2018 Revision :20 Maret 2019 Accepted : 20 Juni 2019

\section{PENDAHULUAN}

Kelapa (Cocos nucifera L.) merupakan salah satu tanaman perkebunan yang paling banyak dibudidayakan di Provinsi Gorontalo. Berdasarkan data BPS tahun 2016 diketahui bahwa dari delapan tanaman perkebunan yang ada di
Gorontalo, tanaman kelapa memiliki luas perkebunan yang terbesar yakni 54.865 hektar dibandingkan dengan tanaman perkebunan lainnya (kakao, kopi, cengkeh, jambu mete, aren, kapuk, vanili). Tanaman ini tersebar di 5 kabupaten yakni kabupaten Gorontalo 22.810 hektar, kabupaten 
Pohuwato 14.312 hektar, kabupaten Gorontalo Utara 8528 hektar, dan kabupaten Boalemo 6862 hektar. Produksi buah kelapa selama 7 tahun terakhir (20102016) juga cukup besar yakni berkisar antara 54.000 ton sampai 67.000 ton pertahun (BPS, 2018). Angka ini tentunya menunjukkan bahwa kelapa dapat menjadi potensi utama bagi masyarakat Gorontalo untuk dapat meningkatkan kesejahteraan hidup jika diolah dan dimanfaatkan sebaikbaiknya.

VCO mempunyai nilai tambah yang besar karena dapat digunakan sebagai bahan baku berbagai produk seperti kosmetik, sabun, makanan dan obatobatan. Virgin Coconut Oil (VCO) harganya bisa mencapai tiga sampai empat kali minyak kelapa biasa. Di pasaran VCO dijual dengan harga bervariasi antara Rp. 35.000 sampai dengan Rp. 50.000 per 350 $\mathrm{ml}$ tergantung kandungan asam larutnya.

Desa Posso merupakan salah satu wilayah di Gorontalo Utara yang masyakatnya banyak bekerja sebagai petani, PNS dan pedagang. Di Desa Posso belum ada pengrajin VCO, padahal potensi kelapa di wilayah ini besar. Oleh karena itu membutuhkan sosialisasi kepada masyarakat cara mengolah kelapa menjadi VCO. Masyarakat biasanya langsung menjual kepada pedagang dengan harga Rp 1000/butir, padahal jika kelapa ini diolah menjadi produk pangan lain dapat meningkatkan penghasilan masyarakat setempat.

VCO merupakan salah satu produk yang dapat di kembangkan karena VCO memiliki produk turunan yang bisa di manfaatkan masyarakat. VCO berfungsi untuk perawatan rambut, perawatan kulit, perawatan tubuh, dan diminum untuk kesehatan tubuh. VCO lebih aman di konsumsi di bandingkan minyak goreng yang beredar di masyarakat saat ini. Adapun permasalahan adalah daerah Posso membutuhkan upaya pelatihan pembuatan VCO sehingga dapat meningkatkan pendapatakan masyarakat.

\section{METODE}

Mitra yang terlibat dalam pengabdian ini adalah masyarakat Desa Posso Kabupaten Gorontalo Utara. Untuk meningkatkan pendapatan masyarakat di Desa Posso yang kurang memiliki jiwa kewirausahaan dilakukan dengan memberi pelatihan pembuatan VCO dari kelapa. Pelatihan dilakukan dengan berbagai tahapan proses, yaitu: 1) tahap persiapan, yaitu survei tempat dilaksanakannya pelatihan, jumlah peserta, menyusun bahan dan alat yang akan disiapkan pada saat pelatihan, menyiapakan materi praktik pembuatan VCO yang akan diberikan pada pelatihan. 2) tahap pelaksanaan, yaitu kegiatan dilaksanakan pada tanggal 08 Januari 2018 pukul 10.00 WITA di rumah produksi Bumdes.

Pelatihan diawali dengan pemberian materi dalam bentuk audio visual maupun manual/panduan bagaimana tahapan dalam pembuatan produk VCO. Peserta juga diberikan pembekalan materi tekait kandungan gizi yang terdapat pada VCO, dan juga pengenalan alat dan bahan penunjang dalam pembuatannya.

Setelah diberikan penyuluhan materi tentang proses pembuatan VCO dan kandungan gizi $\mathrm{VCO}$, mitra PKM yang dipimpin oleh Ibu Iyam Akase dilakukan pendampingan dalam melakukan proses pembuatan produk VCO.Dilanjutkan dengan praktek pembuatan VCO dan penerapan metode yang digunakan untuk membuat VCO. Adapun metode pembuatan VCO yang digunakan adalah metode fermentasi dan menggunakan enzim yang berasal dari alam yakni enzim papain yang berfungsi untuk memisahkan antara krim santan dan minyak VCOyang dihasilkan.

Setelah proses produksi selesai,
dilanjutkan dengan pengemasan
produk.Tim pelaksana PKM juga
memberikan penyuluhan dan sharing
tentang kewirausahaan dan bagaimana
mengemas produk dengan baik dan rapi
agar menarik minat pembeli. Tim
pelaksana PKM juga memberikan desain

JPPM ISSN: 2549 - 8347 (Online)

ISNN: 2579 - 9126 (Print)

Vol. 3 No. 2 September 2019 
produk kepada mitra agar mempermudah mitra untuk mengemas hasil produk VCO dengan tampilan produk yang lebih menarik dan siap dipasarkan.

\section{HASIL DAN PEMBAHASAN}

Tahap awal kegiatan ini dilakukan observasi dan permohonan ijin kepada pihak-pihak terkait berkaitan kegiatan yang akan diadakan, melalui ayahanda kepala Desa Posso didapatkan informasi bahwa di Desa ini terdapat pembinaan Bumdesyang akan mengolah kelapa menjadi produk yang punya nilai jual sehingga dengan program ini dapat menambah penghasilan masyarakat setempat.

Program ini mengangkat tema tentang pelatihan pembuatan VCO yang merupakan turunan produk pengolahan kelapa, VCO biasanya disebut dengan minyak perawan dan merupakan produk olahan kelapa yang banyak dicari oleh masyarakat khususnya mereka yang sadar akan kesehatan, karena kandungannya yang sangat baik untuk kesehatan dan kecantikan, sehingga program ini nantinya akan berkontribusi meningkatkan perekonomian warga setempat.

Adapun tahapan pelatihan meliputi: 1) pelatihan menitikberatkan pada kemampuan kognitif peserta berupa pembekalan materi tekait dengan pembuatan VCO dan kandungan gizi yang terdapat pada VCO tersebut, dan juga pengenalan alat dan bahan penunjang dalam pembuatannya 3) praktek pembuatan VCO dan sharing tentang metode yang digunakan untuk membuat VCO. Adapun metode pembuatan VCO yang digunakan adalah dengan menggunakan enzim yang berasal dari alam yakni enzim papain yang berfungsi untuk memisahkan antara krim santan dan minyak VCO yang dihasilkan.

Adapun Hasil yang dicapai pada pengabdian yang diadakan adalah sebagai berikut:

Dengan adanya pelatihan ini menambah wawasan dan infomasi tentang metode pembuatan VCO dengan kualitas yang baik Masyarakat mengetahui potensi alam yang dapat dimanfaatkan untuk membuat VCO, dalam hal ini dengan enzim papain yang berasal dari getah pepaya dapat mempercepat pemisahan antara krim dan minyak pada santan kelapa.Virgin Coconut Oil (VCO) merupakan modifikasi proses pembuatan minyak kelapa untuk menghasilkan produk dengan kadar air dan kadar asam lemak bebas yang rendah, berbau harum, berwarna bening, dan daya simpan yang cukup lama yaitu lebih dari 12 bulan (Widiyanti, 2015). Teknik pengolahan minyak kelapa menjadi VCO dilakukan dengan menggunakan metode fermentasi dengan beberapa tahapan yaitu: ekstraksi santan dari daging buah kelapa.

Proses ekstraksi santan dimulai dari buah kelapa tua dikupas kemudian dibelah dan dagingnya dikeluarkan dari tempurung. Daging buah kelapa masih diparut secara manual. Hancuran daging buah lalu ditambah air dengan perbandingan 1:2. Selanjutnya, ekstrak dipres secara manual, kemudian disaring sehingga diperoleh santan. Santan yang diperoleh dituang pada ember plastik transparan, kemudian didiamkan selama 2 jam. Selama pendiaman, santan terpisah menjadi tiga lapisan, yaitu lapisan atas berupa krim yang kaya akan minyak, lapisan tengah berbentuk skim yang kaya akan protein, dan lapisan bawah berupa endapan. Krim dipisahkan dan digunakan sebagai bahan baku VCO. Selain itu, tim juga melakukan pencampuran enzim kedalam krim kelapa dan didiamkan selama 24 jam.

Pencampuran enzim ini bertujuan untuk memecah karbohidrat sehingga menghasilkan asam. Asam ini akan menurunkan $\mathrm{pH}$ santan sampai mencapai titik isoelektrik protein sehingga protein akan terkoagulasi. Kemudian enzim akan memecah protein terkoagulasi, akhirnya mudah dipisahkan dari minyak (Rosenthal dan Niranjan, 1996). Setelah itu, dilanjutkan dengan proses pemanasan krim sampai terbentuk minyak dan blondo yang 
berwarna putih. Minyak (VCO) disaring dan dipisahkan. Selanjutnya VCO siap dikemas ke dalam botol. Hasil dari pelatihan dan pendampingan ini berupa pengolahan minyak kelapa menjadi produk VCO yang berbau harum, berwarna bening, dan daya simpan lebih lama seperti pada gambar di bawah ini

Adapun evaluasi pada tahap pertama dengan indikator dan rancangan evaluasi diperoleh sebagai berikut:

1. Jumlah peserta yang hadir adalah seluruh anggota Bumdes yang memang saat ini konsen dalam mengolah kelapa menjadi minyak

2. Keantusiasan peserta pelatihan sangat jelas dimana seluruh peserta terlibat aktif selama kegiatan berlangsung

3. Evaluasi terhadap produk sesuai dengan indikator dan tolak ukur produk yang dihasilkan memiliki tingkat kejernihan

4. Evaluasi terhadap tingkat kesukaan peserta hampir semua peserta menyukai produk yang dihasilkan.

Evaluasi kegiatan pelatihan secara umum berjalan dengan baik dan memuaskan peserta maupun tim pelaksana. Peserta berharap ditahun-tahun kemudian dapat diberikan kesempatan mendapatkan pelatihan sejenis.

\section{SIMPULAN}

Dengan diberikannya pelatihan dan praktek proses pembuatan minyak VCO di lokasi mitra, mitra menjadi lebih menguasai dan paham cara mengolah kelapa menjadi produk yang lebih bermanfaat sehingga mitra dapat memproduksi VCO secara mandiri.

\section{DAFTAR PUSTAKA}

BPS, 2018. Provinsi Gorontalo dalam Angka 2018. Badan Pusat Statistik Gorontalo.

Rindengan, B. 2003. Pengembangan minyak kelapa murni (virgincoconut oil) untuk industri farmasi dan kosmetika. Makalah disampaikan pada Aplikasi Teknologi Pascapanen
Komoditas Perkebunan, Makassar, 2-7 September 2003.

Rosenthal, A.,D.L Pyle, dan K. Niranjan. 1996. Aqueous and Enzymatic Processes for Edible Oil Extractin. Jurnal of Enzymology Microbial Technology. 19; $402-420$.

Widiyanti, R. A. (2015). Pemanfaatan Kelapa Menjadi VCO (Virgin Coconut Oil) sebagai Antibiotik Kesehatan dalam Upaya Mendukung Visi Indonesia Sehat 2015. Prosiding Seminar Nasional Pendidikan Biologi 2015, yang diselenggarakan oleh Prodi Pendidikan Biologi FKIP Universitas Muhammadiyah Malang, 21 Maret 2015. 